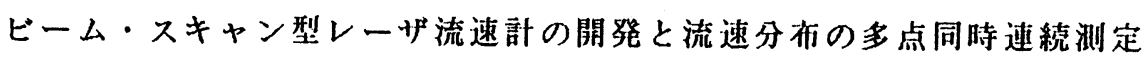
Development of a Beam Scan type LDV for

Sumiltaneous and Continuous Measurement of Velocity Profile

\begin{tabular}{|c|c|c|c|c|c|c|c|}
\hline 東京工業大学 & 工学部 & 正 & 是 & 日 & & & \\
\hline \multicolumn{4}{|c|}{ 日本科学工業株式会朴 } & & & & \\
\hline 東京工業大学 & 工学部 & 正 & 貝 & 澌 & & & \\
\hline 東京工業大学 & 工学部 & & & 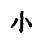 & & & \\
\hline 本科学工 & 社 & & & 村 & & & \\
\hline
\end{tabular}

\title{
1.はしめに
}

現在、流れの埸における流速計測手法は、ピトー管やレーザ流速計（L D V ）などによる固定点での流速 計测手法と、いわゆる流れの可視化法とに大别される。前者は定量的計湘に道している反面、流れの大局的 棈造を捉えるには不向きであり、逆に、後者は流れの全体像を瞬時に把暒する事は容易であるが、定量化に はかなりの労力を要するという久点がある。そこで本研究では、これら2つの手法の長所を誳合させた形の、 新しいタイプの流速計を開発する事を武みた。このような目的のためにいくつかの方法が提案されているが 1)2)、本論文では回転ポリコンミラー方式を採用している。この流速計の原理と基本設計の椹略については すでに前回の本鿁湍会に報告した ${ }^{3)}$ 。すなわち、L D V のレーザ光線をミラーにより高速にスキャンし、あ る断面内の流速分布をほほ瞬時に計测しようとするものである。本報告は、この原理に基ついて武作された ビーム・スキャン型レーザ流速計（S L V ）の具体的な抰成と性能、いくつかの流れを対象とした湘定例、 および現在検討を行なっているスキャンの改良方式について諭じたものである。

\section{2. 本システムの㩲成}

本システムは、レーザ光線をスキャンする方法としてミラーによる反射を利用している。これは後で述へ る新しいスキャン方式でも同じである。最初の試作では、一定速度で回転しているポリコンミラーを用いて レーザ光線の反射方向を変化させる事により、2本のレーザ光線の交叉焦点である澌定点を滈速で線上をス キャンさせる方式のシステムとした（図1）。このシステムの構成を図 2 に示す。光源から発せられたレ一 ザ光楾は光ファイバにより盟射采に導かれる。この照射系にはポリコンミラーが組み込まれており、ここで レーザ光線をスキャンさせている。スキャ ンにより测定点は光粙に対し垂直方向に移 動する。移動する测定点（交叉レーザ光の 焦点での干涉稤）から発せられる散乱光を 一点に導く様、受光系前面にはシリンドリ カルレンスを取り付けてある。この散乱光 は、光電変换器、シグナルプロセッサ、 $\mathrm{A}$ /D变换器を通してコンピュータで処理が 可能な流速データとなる。他方、スキャン ドライバはポリコンミラーの回転速度の制 御を行なうと共に、ポリゴンミラーの回転 角度、すなわち澌定点の位置を示すアドレ スデータを出力する。この 2 つのデータは

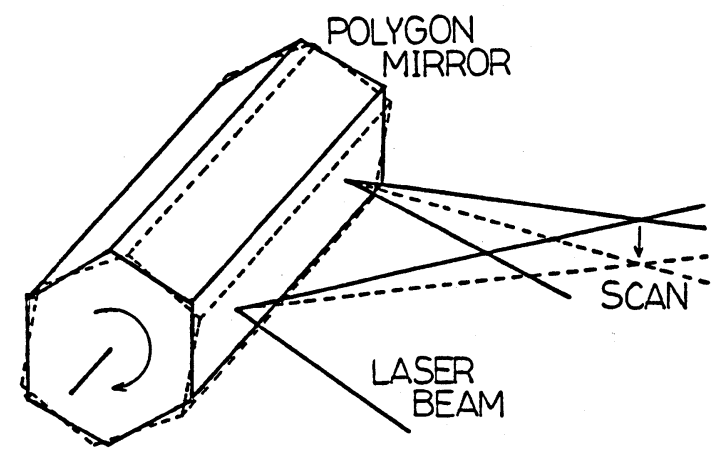

図 1 S L V 用ボリゴンミラー 同時にバッファ・メモリに蓄えられる。ま 


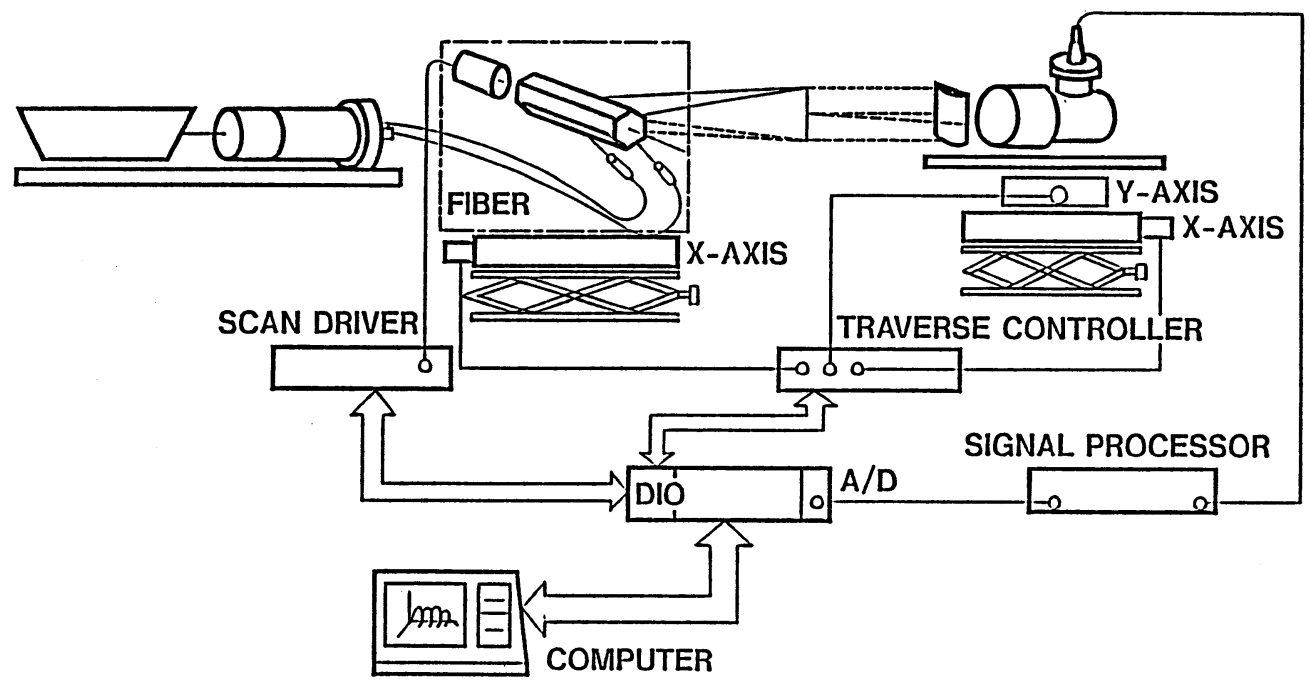

图2ビームスキャン型レーザ流逨計の權成図

た、本システムにはイメージ・センサ（CＣＤ）を用いたオート・フォーカス機棈が組込まれている。この 譏搟により高速スキャン時のフォーカス・チェックを行うことができ、きらに湘定断面を变える時などには その受光系の焦点合わせをコンピュータから制御する事も可能である。

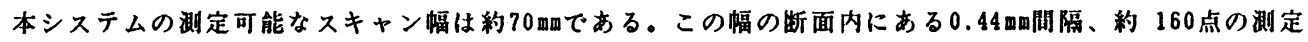

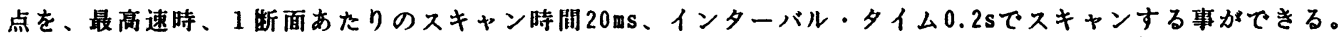

\section{3、スキャン方式の改良策の検封}

武作第一号の回転ポリコンミラー方式では、システムを最高速で使用した時 1 つの测定点には約 $60 \lll \mathrm{Sしか}$ 計測時間がない。この時間はトレーサー粒子からの散乱光信号をシグナルプロセッサが処理するにはやや短 すき、信号のドロップアウトが 生じる事がある・そこでスキャ ン方式の改良を戴みた。新しい スキャン方式はポリコンミラー を回転させるの代わりに、1枚 の板ミラー（実際にはポリコン ミラーの一面のみを利用する) を順転・逆転運動させる事によ り湘定点をスキャンさせる「リ バース方式」である（図3）。 武作設計時の段階でも、このミ ラーをリバースさせる方式は当 然検討されたが、この際にはミ

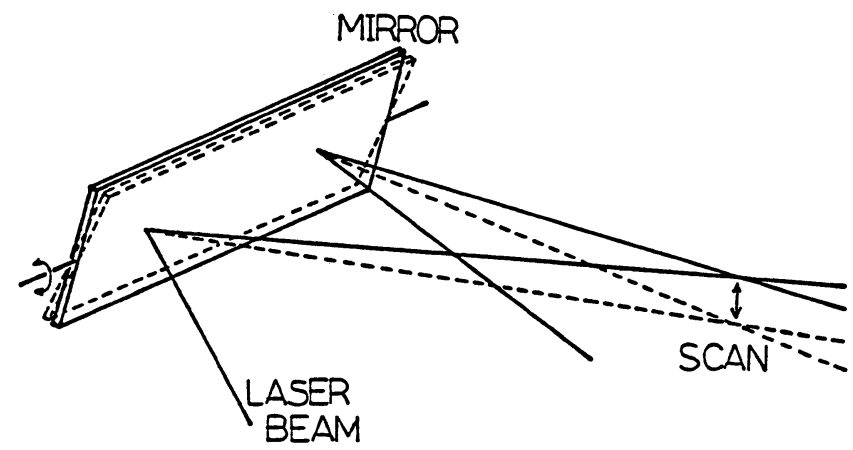

図3リバース・スキャン方式 
ラー駆動系に機械的な無理がかかるであろうとして採用しなかったのである。このスキャン方式により改善 される点は下記の 4 点である。

（1）スキャン幅が可变である ：スキャン幅を狭くすれは、スキャンのインターバル・タイ ムをさらに短くできる。

（2）ブランク・タイムが減少する：今まではブランク・タイム（干渉棉からの散乱光が受光录 に受光されない時間）が90\%を占めていたが、リバース式で はスキャン幅を調整することにより、これを０\%にする事も 可能。

（3）データ・レートが增加する ：同一条件下において、リバース式スキャンでは娜定点に留 っている時間がポリコンミラーによるスキャンの時の約10倍 となり、それゆえ安定した計揤が行なえる。

（4）測定点の变動が少ない

： ミラーを1枚しか用いないので、レーザ光線のスキャン方 向とは垂直な方向へのレーザ光焦点のズレがない。つまり、 ポリコンミラー方式では回転により反射面が变わることに回 転䡛からの微小倔心があるが、1枚ミラーではその心配がな い。これにより、测定点位置の信頼性が向上したばかりでな く受光系内のスリットも䎩くできるので $\mathrm{S} / \mathrm{N}$ 比が向上する。

しかし、リバース式について新たに閆題となるのは、

前にも述べたように、反転時の慣性力により機栈部

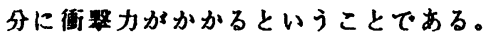

表 1 交番振動流の測定条件

\begin{tabular}{|cc|c|}
\hline 実験条件 & 值 \\
\hline$\omega$ & {$[\mathrm{rad} / \mathrm{s}]$} & 1.45 \\
$U_{0}$ & {$[\mathrm{~m} / \mathrm{s}]$} & 1.21 \\
5 & {$[\mathrm{~m}]$} & $4.12 \times 10^{-3}$ \\
$R_{0}$ & & 400 \\
$R_{0}$ & & $8.2 \times 10^{4}$ \\
$\lambda$ & 12.1 \\
スキャン間隔 & $\mathrm{s}]$ & 0.2 \\
\hline
\end{tabular}

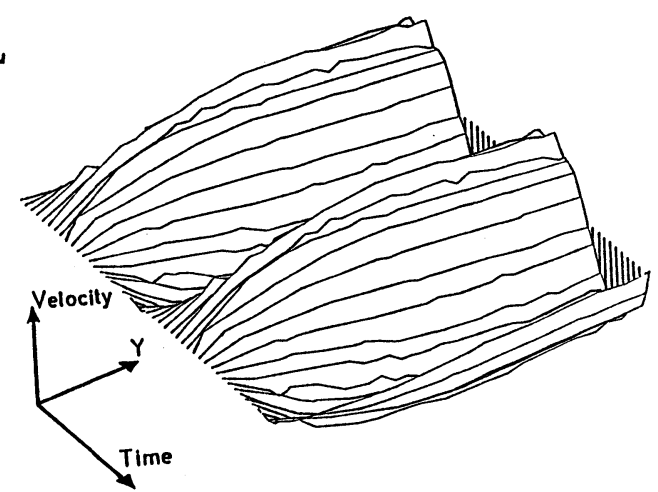

b 流速分布の三次元表示

図4 交番振動流壁面付近の流速分布 


\section{4. 揤定結果}

本システムを用いた测定例として、交番振動流とカルマン瀜について計测した結果を示す。

\section{(1) 交番振動流}

矩形断面（幅 $26.0 \mathrm{~cm} \times$ 高さ $10.0 \mathrm{~cm}$ ）管路内に おける空気振動流の壁面付近の層流の流速分布 をポリコンミラーを用いたスキャン方式で計测 した。その测定条件および渭定結果を表 1、困 4に示す。ただしトレーサには煙より粒径の大 きい箖を用いている。

この测定䊅果は、ほほ理論値に合っている事 から妥当な䊅果が得られたといえる。

(2)カルマン洞

伦急的に上記のリバース・スキャン方式で駆 動し計湘したカルマン洞の湘定条件を表 2 、测 定結果を図 5 に示す。この流速べクトル図は測 定䊅果をティラーの凍䊅流速埸の仮説（Frozen Flowfield）および連続条件式を用いることに より図化したものである。
表2 カルマン渦の測定条件

\begin{tabular}{|cc|c|}
\hline 実験条件 & 値 \\
\hline$U$ & {$[\mathrm{~cm} / \mathrm{s}]$} & 7.55 \\
$U-V_{v}$ & {$[\mathrm{~cm} / \mathrm{s}]$} & 5.78 \\
$S_{t}$ & & 0.28 \\
$R_{\theta}$ & & 900 \\
$f$ & {$[1 / \mathrm{s}]$} & 1.33 \\
$b$ & {$[\mathrm{~cm}]$} & 4.33 \\
$d$ & {$[\mathrm{~cm}]$} & 1.6 \\
& & 0.3 \\
\hline
\end{tabular}

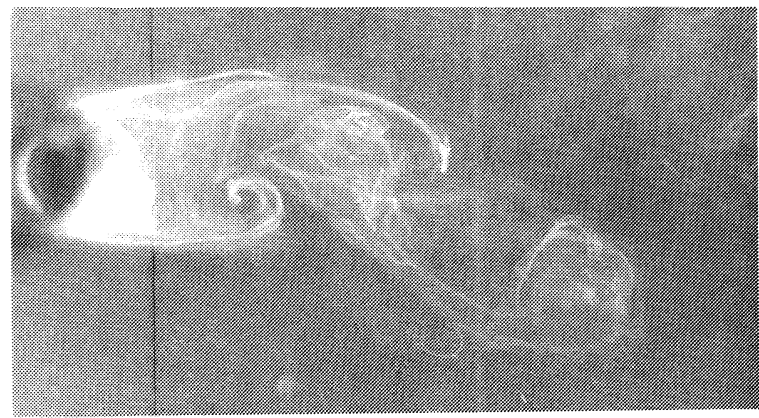

a 测定対豕:のカルマン瀜

测定断面
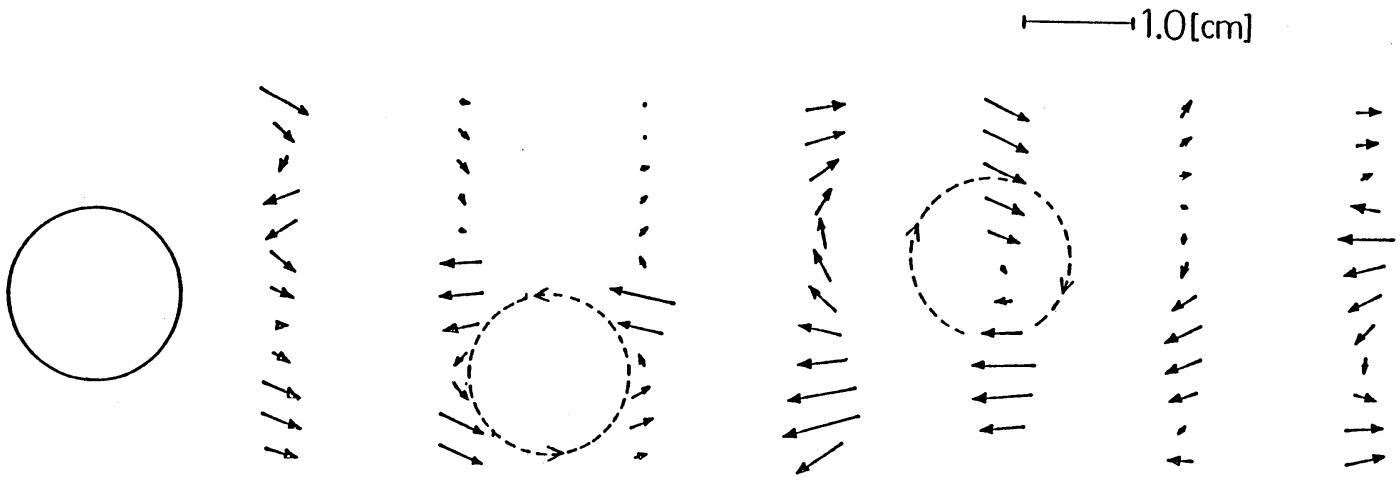

b 流速ベクトル図

図5 カルマン渦 
5.おわりに

本論文によって、流れの場の一直線上の瞬間流速の变化をはほ連続的に計测することを目的としてビーム ・スキャン型L D Vを開発したことを示した。また、その有効性についても测定結果をもちいて示した。今 後、空間的・時間的により密なデー夕を得られるようスキャン方式の改良・改造をすすめると共に、测定で 得られたデータの処理方法・表示方法についても検討してゅくつもりである。

6. 铸辞

本研究は、文部省科学研究数試験研究（1）「ビーム・スキャン型レーザー・ドップラー法による流速埸 の多点同時連䊦計测システムの開発」（代表者・東工大・日野幹雄）の援助によって行なっているものであ る。ここに、厚く皦意を表わしたい。

\section{7.夌考文献}

1 ）池田裕二・松本隆一・中岛健・堀昭・岛田幸雄(1985)：流れの計测と可視化に関するジョイント鿁演 要旨集 $\mathrm{pp} 43 \sim 48$

2) 日野幹雄・灌同和夫・広永勝治・村本龍夫(1985)：第 17 回乱流シンポジウム $\mathrm{pp} 178 \sim 181$

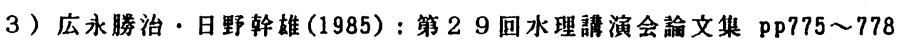

